\title{
ANALISA PENGARUH KARAKTERISTIK PERUSAHAAN TERHADAP TINGKAT PENGUNGKAPAN TANGGUNG JAWAB SOSIAL PERUSAHAAN PADA PERUSAHAAN HIGH PROFILE YANG TERCATAT DI BURSA EFEK INDONESIA PADA TAHUN 2005-2007
}

\author{
Muhammad Yusuf \\ Jurusan Akuntansi, Fakultas Ekonomi dan Bisnis, Bina Nusantara University \\ Jl. K.H. Syahdan No. 9, Kemanggisan, Palmerah, Jakarta Barat 11480
}

\begin{abstract}
This research is to examine corporate social responsibility disclosure and its level in Indonesian companies. Based on a review of previous researches, six independents variables are extracted for a multiple regression analysis. They are company size, profitability, age, leverage, liquidity, and public ownership. The technique for examining multiple regression analysis by using spss 11,5 programs. Samples of this research are 41 high profile companies that listed in Indonesia Stock Exchange in 2005, 2006, and 2007 acquired using purposive sampling method. The results of this research sowed that on significance rate of 5\%, the company size, age, leverage, and liquidity has a significance effect with corporate social responsibilities disclosures. While for the profitability and public ownership has no effect with corporate social responsibilities. These results generally coincide with previous research findings on corporate social responsibilities disclosures.
\end{abstract}

Keywords: corporate social responsibility, company size, profitability, age, leverage, liquidity, public ownership

\begin{abstract}
ABSTRAK
Penelitian ini bertujuan untuk menguji pengungkapan tanggung jawab sosial perusahaan dan tingkat pengungkapan tanggung jawab sosial di perusahaan Indonesia. Variabel independen yang dimaksud adalah ukuran perusahaan, profitabilitas, umur perusahaan, leverage, likuiditas dan kepemilikan publik. Teknik analisis regresi berganda ini akan dianalisa menggunakan program SPSS 11,5. Sampel dari penelitian ini adalah 41 perusahaan high profile yang tercatat di Bursa Efek Indonesia pada tahun 2005, 2006, dan 2007 dengan pengambilan sampel menggunakan metode purposive sampling. Hasil dari penelitian ini dengan menggunakan signifikan level 5\% menunjukan bahwa ukuran perusahaan, umur perusahaan, leverage dan likuiditas mempengaruhi pengungkapan tanggung jawab sosial perusahaan. Sedangkan profitabilitas dan kepemilikan publik tidak mempunyai pengaruh dalam pengungkapan tanggung jawab sosial perusahaan. Hasil dari penelitian ini umumnya sama dengan penelitian sebelumnya mengenai pengungkapan tanggung jawab sosial perusahaan.
\end{abstract}

Kata kunci: pengungkapan tanggung jawab sosial perusahaan, ukuran perusahaan, profitabilitas, umur perusahaan, leverage, likuiditas, kepemilikan public 


\section{PENDAHULUAN}

\section{Latar Belakang Masalah}

Permasalahan sosial yang sekarang ini banyak terjadi di masyarakat menjadi isu yang hangat diperbincangkan banyak pihak. Masalah sosial yang saat ini menjadi sorotan berbagai pihak tersebut adalah munculnya isu tanggung jawab sosial dan kepedulian sosial terhadap lingkungan dan masyarakat. Menurut Grey et al. dalam Sembiring (2006), tumbuhnya kesadaran publik akan peran perusahaan di tengah masyarakat melahirkan kritik karena menciptakan masalah sosial, polusi, sumber daya, limbah, mutu produk, tingkat safety produk, serta hak dan status tenaga kerja. Timbulnya kesadaran publik terhadap peran perusahaan di masyarakat semakin meningkat, dapat dilihat bahwa banyak perusahaan yang dianggap telah memberi kontribusi bagi kemajuan ekonomi dan teknologi tetapi perusahaan tersebut mendapat kritik karena telah menciptakan masalah sosial. Hal ini disorot melalui kritikan yang dilontarkan Ramanathan dalam Yuningsih (2004) yang menyatakan bahwa penyelesaian masalah lingkungan hidup tidak bisa dilepaskan dari keterlibatan secara aktif perusahaan di dalamnya.

Salah satu tanggung jawab sosial perusahaan adalah dengan memberikan informasi yang dibutuhkan oleh investor dan manajemen tetapi juga pada masyarakat luas. Tanggung jawab sosial perusahaan-perusahaan itu sendiri dapat digambarkan dengan ketersediaan informasi keuangan dan non-keuangan berkaitan dengan interaksi organisasi dengan lingkungan fisik dan lingkungan sosialnya, yang dapat dibuat dalam laporan tahunan atau laporan terpisah (Guthrie \& Mathews dalam Sembiring 2002).

Perusahaan perlu melaporkan atau menyampaikan seluruh informasi mengenai aktivitasnya, baik yang berkaitan dengan kegiatan perusahaan maupun kegiatan sosial sebagai bentuk pertanggungjawaban kepada berbagai pihak khususnya kepada stakeholder. Informasi yang disampaikan dapat disajikan dalam laporan tahunan yang tidak hanya digunakan sebagai alat pertanggungjawaban kepadda pemilik modal atas pengelolaan dana, tetapi juga sebagai alat pertanggung jawaban sosial. Hal ini didukung oleh Ikatan Akuntan Indonesia (IAI) yang telah mengeluarkan Pernyataan Standar Akuntansi Keuangan (PSAK) no.1 (revisi 1998) paragraf sembilan secara implisit menyarankan untuk mengungkapkan tanggung jawab akan masalah sosial dimana perusahaan menyajikan laporan tambahan mengenai lingkungan hidup dan laporan nilai tambah, khususnya bagi industri dimana lingkungan hidup dan kelompok sebagai pegawai pengguna memegang peran penting. Pernyataan senada juga terdapat dalam tujuan laporan keuangan no.12 dalam Trueblood Report, yaitu tujuan laporan keuangan adalah untuk melaporkan aktivitas perusahaan yang mempengaruhi komunitas yang mana dianggap penting bagi perusahaan dalam lingkungan sosialnya.

Pada masalah ini penulis melihat pentingnya tanggung jawab sosial yang harus diperhatikan oleh perusahaan, sekaligus melanjutkan penelitian dari Sembiring (2006) dengan menambahkan variabel baru yaitu umur perusahaan, likuiditas dan kepemilikan publik. Penulis termotivasi untuk membahas lebih lanjut untuk menyusun skripsi ini dengan judul Analisa Pengaruh Karakteristik Perusahaan Terhadap Tingkat Pengungkapan Tanggung Jawab Sosial Perusahaan Pada Perusahaan High Profile yang Tercatat di Bursa Efek Indonesia pada Tahun 2005-2007.

\section{Perumusan Masalah}

Berdasarkan latar belakang yang telah dikemukakan di atas, maka permasalahan yang akan dibahas dalam penelitian ini adalah: (1) bagaimanakah tingkat pengungkapan tanggung jawab sosial perusahaan yang dilakukan oleh perusahaan high profile yang terdaftar di Bursa Efek Indonesia; (2) apakah terdapat pengaruh ukuran perusahaan terhadap pengungkapan tanggung jawab sosial 
perusahaan; (3) apakah terdapat pengaruh profitabilitas terhadap pengungkapan tanggung jawab sosial perusahaan; (4) apakah terdapat pengaruh umur perusahaan terhadap pengungkapan tanggung jawab sosial perusahaan; (5) apakah terdapat pengaruh leverage terhadap pengungkapan tanggung jawab sosial perusahaan; (6) apakah terdapat pengaruh likuiditas terhadap pengungkapan tanggung jawab sosial perusahaan; (7) apakah terdapat pengaruh kepemilikan publik terhadap pengungkapan tanggung jawab sosial perusahaan.

\section{Tujuan dan Manfaat Penelitian}

Tujuan Penelitian adalah untuk mengetahui tingkat pengungkapan tanggung jawab sosial perusahaan yang dilakukan oleh perusahaan high profile yang terdaftar di Bursa Efek Indonesia yang diukur berdasarkan ukuran perusahaan, profitabilitas perusahaan, umur perusahaan, pengaruh leverage, pengaruh likuiditas, pengaruh kepemilikan publik terhadap pengungkapan tanggung jawab sosial perusahaan dan manfaat penelitian adalah memberikan kontribusi terhadap pengembangan pengungkapan tanggung jawab sosial pada perusahaan di Indonesia.dan bagi perusahaan sebagai masukan bagi perusahaan di Indonesia agar lebih memperhatikan kondisi sosial dan lingkungannya yang berpengaruh terhadap masyarakat luas.

\section{Landasan Teori}

\section{Pengertian Tanggung Jawab Sosial Perusahaan}

Beberapa definisi mengenai tanggung jawab sosial perusahaan (corporate social responsibility). Menurut Budiarsi (2005), pengertian dari tanggung jawab sosial perusahaan yaitu praktek bisnis transparan, yang didasari pada nilai-nilai etika, dengan memberikan perhatian pada karyawan, masyarakat dan lingkungan, serta dirancang untuk dapat melestarikan masyarakat secara umum dan juga para pemegang saham. Menurut Januarti \& Apriyanti (2005), pengertian dari tanggung jawab sosial perusahaan yaitu: "Kewajiban organisasi yang tidak hanya menyediakan barang dan jasa yang baik bagi masyarakat, tetapi juga mempertahankan kualitas lingkungan sosial maupun fisik, dan juga memberikan kontribusi positif terhadap kesejahteraan komunitas dimana mereka berada” (p. 230). Sementara, menurut Purwanto (2006), pengertian dari tanggung jawab sosial perusahaan yaitu: "Tindakan-tindakan dan kebijakan-kebijakan perusahaan dalam berinteraksi dengan lingkungannya yang didasarkan pada etika” (p. 83).

\section{Latar Belakang Tanggung Jawab Sosial Perusahaan}

Menurut Purwanto (2006) terdapat tiga pendekatan dalam pembentukan tanggung jawab sosial perusahaan, yaitu: pendekatan moral, pendekatan kepentingan bersama dan pendekatan manfaat. Menurut Januarti \& Apriyanti (2005), ada tiga perspektif yang timbul berkaitan dengan tanggung jawab sosial perusahaan (corporate social responsibility), yaitu: (1) perspektif bisnis yang menganggap pentingnya reputation capital; (2) perspektif eco-social memandang tanggung jawab sosial perusahaan sebagai nilai (value) dan strategi untuk menjamin kelangsungan hidup perusahaan; (2) right-based perspective menekankan bahwa konsumen, pekerja, masyarakat, dan pemegang saham mempunyai hak untuk mengetahui kegiatan bisnis perusahaan. Aspek kunci dari tanggung jawab sosial perusahaan adalah akuntabilitas, transparansi, dan investasi sosial dan lingkungan.

Menurut Harahap (2001), penyebab timbulnya tanggung jawab sosial adalah “Adanya pergeseran dari orientasi pada shareholders ke stakeholders yaitu kecenderungan yang bergerak dari kegiatan mencari keuntungan yang sebesar-besarnya tanpa melihat efek samping ke arah mencari laba yang berwawasan lingkungan” (p. 350). Menurut Harahap (2001:351-352) kecenderungan itu semua dapat kita lihat dari beberapa paradigma berikut ini: "Kecenderungan terhadap kesejahteraan sosial, negara tidak bisa hidup sendiri tanpa partisipasi rakyatnya, perusahaan juga tidak akan maju tanpa dukungan langganannya maupun lingkungan sosialnya. Kenyataan ini semakin disadari dan semakin 
dibutuhkan pertanggungjawabannya. Kecenderungan terhadap kesejahteraan lingkungan, perspektif ekosistem, orientasi yang terdahulu diarahkan pada pembangunan ekonomi efisiensi, profit maximation dan menimbulkan krisis ekosistem, orientasi ekonomi vs Orientasi sosial” (pp. 351-352).

Menurut Januarti \& Apriyanti (2005 : 231-232) menyatakan bahwa: pada dasarnya kemauan untuk melaksanakan tanggung jawab sosial (social responsibility) tergantung pada tingkat kepekaan sosial (social sensitiveness) manajemen perusahaan, dimana tingkat kepekaan pengelola perusahaan adalah merupakan akumulasi dari tingkat kepekaan masing-masing individu yang menduduki berbagai tingkat jabatan organisasi perusahaan yang bersangkutan” (pp. 231-232).

\section{Akuntansi Pertanggungjawaban Sosial}

Menurut Rajafi \& Irianto (2007), Di antara pendapat-pendapat para ahli yang mengemukakan pengertian akuntansi pertanggungjawaban sosial, masing-masing pendapat sifatnya hanya melengkapi satu sama lain, belum ada kesepakatan definisi yang pasti. Bahkan dalam penetapan istilah pun belum ditemukan keseragaman ada yang menyebut disiplin itu sebagai Akuntansi Pertanggungjawaban Sosial, sebagian lagi memakai istilah Akuntansi Sosial Ekonomi, dan adapula yang menyebutnya Akuntansi Sosial.

Standar Akuntansi Keuangan yang dikeluarkan Ikatan Akuntan Indonesia (2002), telah mengeluarkan Pernyataan Standar Akuntansi Keuangan (PSAK) no.1 (revisi 1998) paragraf sembilan menyatakan bahwa perusahaan dapat pula menyajikan laporan tambahan seperti laporan mengenai lingkungan hidup dan laporan nilai tambah (value added statement), khususnya bagi industri dimana faktor-faktor lingkungan hidup memegang peran penting dan bagi industri yang menganggap pegawai sebagai kelompok pengguna laporan yang memegang peranan penting.

Pernyataan senada juga terdapat dalam tujuan laporan keuangan no.12 dalam Trueblood Report, yaitu bahwa tujuan laporan keuangan adalah untuk melaporkan aktivitas-aktivitas perusahaan yang mempengaruhi komunitas yang mana dapat ditentukan dan dijelaskan atau diukur dan penting bagi perusahaan dalam lingkungan sosialnya. Lalu, menurut Rajafi \& Irianto (2007), laporan Akuntansi Pertanggungjawaban Sosial yang disajikan perusahaan bersifat sukarela, ini berarti bahwa perusahaan tidak harus untuk menyajikan laporan pertanggungjawaban sosial ini. Laporan ini tidak hanya melaporkan hasil dari proses mengidentifikasi, mengukur, dan menilai segala bentuk kegiatan yang berhubungan dengan kegiatan sosial perusahaan tetapi sekaligus juga mempengaruhi pihak eksternal khususnya dalam hal pengambilan keputusan.

\section{Pengungkapan}

\section{Pengertian pengungkapan}

Menurut Chariri \& Ghozali (2003), pengertian pengungkapan (disclosure) yaitu: "Tidak menutupi atau tidak menyembunyikan. Apabila dikaitkan dengan data, pengungkapan berarti memberikan data, pengungkapan berarti memberikan data yang bermanfaat kepada pihak yang memerlukan. Apabila dikaitkan dengan laporan keuangan, pengungkapan mengandung arti bahwa laporan keuangan harus memberikan informasi dan penjelasan yang cukup mengenai hasil aktivitas suatu unit usaha” (p. 235). Dalam Pernyataan Standar Akuntansi Keuangan (PSAK) mengenai Kerangka Dasar Penyusunan Penyajian Laporan Keuangan (2002) paragraph 24 menyatakan bahwa karakteristik kualitatif merupakan ciri khas yang membuat informasi dalam laporan keuangan berguna bagi pemakai. Terdapat empat karakteristik kualitatif pokok, yaitu: dapat dipahami, relevan, keandalan, serta dapat dibandingkan. Menurut Chariri \& Ghozali (2003) ada 3 konsep mengenai luas pengungkapan laporan keuangan, yaitu: pengungkapan yang cukup (adequate disclosure), pengungkapan yang wajar (fair disclosure), dan pengungkapan yang lengkap (full disclosure). 


\section{Pengungkapan Tanggung jawab Sosial Perusahaan}

Menurut Devina, Suryanto \& Zulaika (2004), pengertian dari pengungkapan tanggung jawab sosial perusahaan yang sering disebut juga sebagai corporate social responsibility yaitu: "Proses pengkomunikasian dampak sosial dan lingkungan dari kegiatan ekonomi organisasi terhadap kelompok khusus yang berkepentingan dan terhadap masyarakat secara kesuluruhan” (p. 164). Menurut Anggraini (2006), Standar Akuntansi Keuangan di Indonesia belum mewajibkan perusahaan untuk mengungkapkan informasi sosial terutama informasi mengenai tanggung jawab perusahaan terhadap lingkungan, akibatnya yang terjadi di dalam praktik perusahaan hanya dengan sukarela mengungkapkannya. Perusahaan akan mempertimbangkan biaya dan manfaatt yang akan diperoleh ketika mereka memutuskan untuk mengungkapkan informasi sosial. Bila manfaat yang akan diperoleh dengan pengungkapan informasi tersebut lebih besar dibandingkan biaya yang dikeluarkan untuk mengungkapkannya maka perusahaan akan dengan sukarela mengungkapkan informasi tersebut

Harahap (2001) menguraikan bentuk kegiatan yang dapat dilakukan perusahaan sebagai bukti keterlibatan sosialnya, yaitu: lingkungan hidup, energi, sumber daya manusia dan pendidikan, praktik bisnis yang jujur, membantu masyarakat lingkungan, kegiatan seni dan kebudayaan, hubungan dengan pemegang saham dan hubungan dengan pemerintah. Menurut Harahap (2001), selain yang dikemukakan di atas, masih banyak hal-hal yang dapat dikemukakan sesuai dengan keadaan, baik yang dialami oleh masyarakat maupun potensi yang dimiliki oleh perusahaan namun yang terpenting diingat adalah bahwa kegiatan ini menyangkut keterlibatan perusahaan dalam kegiatan sosial.

\section{Penelitian Terdahulu}

Berbagai penelitian yang terkait dengan pengungkapan tanggung jawab sosial perusahaan sudah banyak dilakukan. Henny \& Murtanto (2001) melakukan penelitian terhadap laporan tahunan 1999 pada 58 perusahaan yang go public di Bursa Efek Jakarta. Hasilnya menunjukan bahwa pengungkapan sosial di Indonesia masih relative rendah yaitu 41,32\%. Penelitian yang berkaitan dengan profile perusahaan kebanyakan mendukung bahwa industri high profile mengungkapkan informasi tentang tanggung jawab sosialnya lebih banyak dari industri low profile. Penelitian yang mendukung hubungan ini antara lain Hackstone \& Milne (1996), Utomo (2000), Kokubu et. al., (2001), Henny \& Murtanto (2001), dan Hasibuan (2001). Penelitian yang menunjukan adanya hubungan yang signifikan antara ukuran perusahaan dengan pengungkapan tanggung jawab sosial yang dilakukan oleh Hackstone \& Milne (1996) dan Sembiring (2006), Gray et. al. (2001) tidak menemukan adanya hubungan.

Adapula penelitian yang menyangkut akan adanya hubungan kinerja keuangan dengan pengungkapan tanggung jawab sosial, dalam penelitian ini kinerja keuangan yang diambil adalah profitabilitas. Akan tetapi hasil yang diperoleh beraneka ragam, hasil penelitian di Jepang oleh Suda \& Kokubo (1994) tidak menemukan hubungan yang signifikan. Pada sisi lain, Freedman \& Jaggi (1988) menemukan suatu hubungan positif antara pengungkapan informasi dan kinerja keuangan. Peenelitian mengenai umur prusahaan telah dilakukan oleh Sembiring (2003) dengan hasil bahwa terdapat hubungan positif antara umur perusahaan dengan pengungkapan tanggung jawab sosial perusahaan.

Roberts (1992) melakukan penelitian mengenai hubungan antara leverage dan pengungkapan tanggung jawab sosial, dimana ketergantungan pada hutang akan membuat perusahaan mengungkapkan tanggung jawab sosialnya. Hasil ini bertentangan dengan yang diperoleh Belkaoui \& Karpik (1989), Cormier \& Magnan (1999), serta Sembiring (2003). Penelitian Marwata (2006) mendapatkan bahwa tidak berhasil menemukan hubungan yang signifikan terhadap pengungkapan sosial perusahaan. Penelitian mengenai likuiditas telah dilakukan oleh Marwata (2006) menunjukan bahwa terdapat hubungan positif antara likuiditas dengan pengungkapan tanggung jawab sosial perusahaan. Pada penelitian Sembiring (2003) menerangkan bahwa adanya pengaruh negative signifikan antara kepemilikan publik dan pengungkapan tanggung jawab sosial. 


\section{Kerangka Pemikiran}

Selanjutnya disampaikan pemikiran teoritis yang menggambarkan suatu kerangka konseptual yang merupakan alur pikir dan sebagai perumusan hipotesi dalam bentuk model penelitian seperti pada Gambar 1.

Gambar 1 Skema Kerangka pemikiran

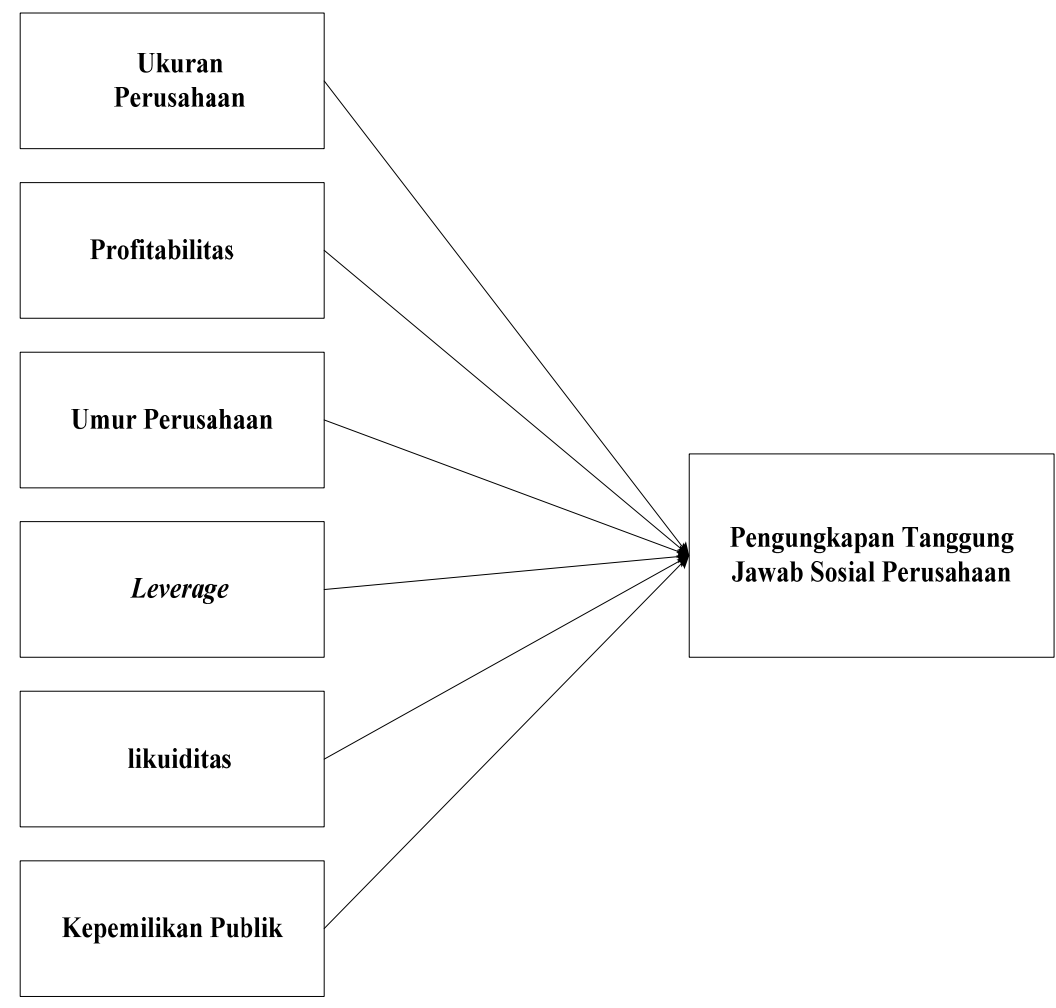

\section{Perumusan Hipotesis}

Berdasarkan tinjauan pustaka, penelitian terdahulu dan kerangka pemikiran yang ada maka perumusan hipotesis yaitu: (1) $\mathrm{Ha}_{1}$ : ukuran perusahaan berpengaruh terhadap pengungkapan tanggung jawab sosial perusahaan; (2) $\mathrm{Ha}_{2}$ : profitabilitas berpengaruh terhadap pengungkapan tanggung jawab sosial perusahaan; (3) $\mathrm{Ha}_{3}$ : umur perusahaan berpengaruh terhadap pengungkapan tanggung jawab sosial perusahaan; (4) $\mathrm{Ha}_{4}$ : leverage berpengaruh terhadap pengungkapan tanggung jawab sosial perusahaan; (5) $\mathrm{Ha}_{5}$ : likuiditas berpengaruh terhadap pengungkapan tanggung jawab sosial perusahaan; (6) $\mathrm{Ha}_{6}$ : kepemilikan Publik berpengaruh terhadap pengungkapan tanggung jawab sosial perusahaan.

\section{METODE PENELITIAN}

\section{Rancangan Penelitian}

Rancangan penelitian yang akan digunakan dalam penelitian ini dengan metode regresi linear berganda. Variabel yang akan digunakan pada penelitian ini adalah variabel independen yaitu ukuran perusahaan, profitabilitas, umur perusahaan, leverage, likuiditas serta kepemilikan publik dan variabel 
dependen yaitu pengungkapan tanggung jawab sosial perusahaan. Dalam penelitian ini, peneliti menggunakan data sekunder, data tersebut diambil dari Bursa Efek Indonesia (BEI), internet dan studi kepustakaan.

\section{Variabel Penelitian dan Pengukuran}

Variabel yang digunakan dalam penelitian ini terdiri dari dua macam yaitu variabel bebas (independent variable) dan variabel terikat (dependent variable). Variabel bebas (independent variabel) dalam penelitian ini terdiri dari Ukuran perusahaan, profitabilitas, umur perusahaan, leverage, likuiditas dan kepemilikan Publik.

Variabel tidak bebas (dependent variable), variabel dependen dalam penelitian ini adalah pengungkapan tanggung jawab sosial perusahaan yang diukur berdasarkan persentase jumlah pengungkapan tanggung jawab sosial perusahaan. Skala pengukuran dari variabel ini adalah skala rasio. Pengungkapan sosial adalah data yang digunakan perusahaan berkaitan dengan aktivitas sosial yang dilakukan oleh perusahaan yang meliputi tema sebagai berikut : lingkungan, energi, keselamatan dan kesehatan kerja karyawan, lain-lain tenaga kerja, produk keterlibatan dan masyarakat dan umum.

\section{Teknik Pengumpulan Data}

Data yang digunakan dalam penelitian ini adalah data sekunder. Data sekunder merupakan sumber data penelitian yang diperoleh peneliti secara tidak langsung melalui media perantara (diperoleh dan dicatat melalui pihak lain) atau data yang telah diolah seperti data hasil penelitian kepustakaan, hasil dokumentasi penelitian dan laporan yang berhubungan dengan penelitian ini. Studi dokumentasi data Studi dokumentasi data diperoleh dari Bursa Efek Indonesia (BEI), Indonesia Capital Market Directory (ICMD) dan internet yaitu laporan keuangan tahunan dari tahun 2005-2007.

\section{Pemilihan Sampel}

Metode pemilihan sampel yang digunakan adalah purposive sampling dimana pemilihan sampel mempunyai tujuan atau kriteria tertentu. Jumlah sampel yang telah memenuhi kriteria sebanyak 42 perusahaan, dengan kriteria sebagai berikut: (1) perusahaan high profile yang terdaftar di Bursa Efek Indonesia pada tahun 2005 sampai 2007 yang telah mempublikasikan laporan tahunannya dari tahun 2005 sampai 2007; (2) perusahaan high profile yang terdaftar di Bursa Efek Indonesia yang mengungkapkan tanggung jawab sosial perusahaan di dalam laporan tahunan pada tahun 2005 sampai 2007; (3) perusahaan high profile yang memiliki net income dan return on assets yang positif selama tahu 2005 sampai 2007.

\section{Metode Analisis data}

Penelitian ini dilakukan dengan tahap-tahap, yaitu uji normalitas, uji asumsi klasik, dan pengujian hipotesis. Pengujian normalitas bertujuan untuk mengetahui apakah dalam model regresi variabel independen dan variabel dependen keduanya terdistribusi normal ataukah tidak. Model regresi yang baik adalah memiliki distribusi data normal atau mendekati normal. Salah satu cara uji normalitas dengan uji kolmogorov-aminov. Uji asumsi klasik merupakan uji multikolinearitas, uji heteroskedastisitas dan uji autokorelasi.

Pengujian hipotesis yang digunakan untuk penelitian ini adalah model regresi berganda karena penelitian memiliki satu variabel dependen dan lebih dari satu variabel independent. Pengujian hipotesis melalui pengujian, Koefisien Determinasi, uji Simultan (Uji F) dan uji Partial (Uji T). Adapun model regresi ini ditujukan dengan persamaan: 


$$
\mathbf{Y}=\mathbf{a}+\mathbf{b}_{1} \mathbf{X}_{1}+\mathbf{b}_{2} \mathbf{X}_{2}+\mathbf{b}_{3} \mathbf{X}_{3}+\mathbf{b}_{4} \mathbf{X}_{4}+\mathbf{b}_{5} \mathbf{X}_{5}+\mathbf{b}_{6} \mathbf{X}_{6}+\mathbf{e}
$$

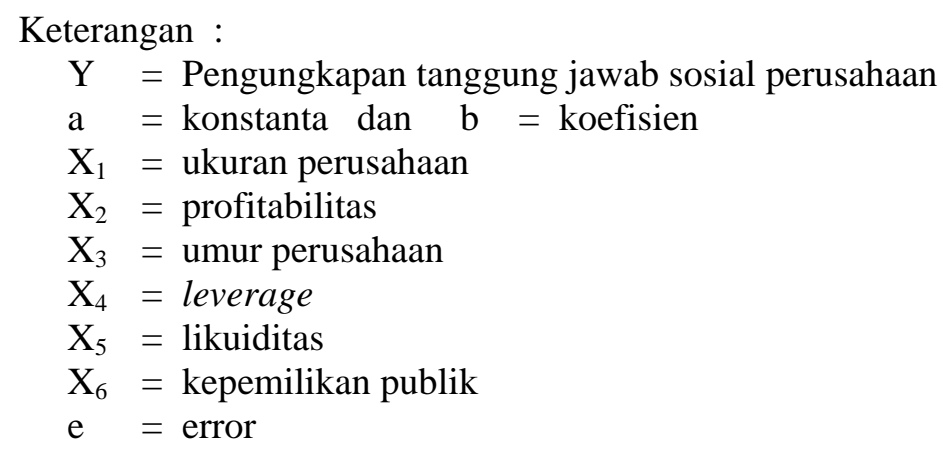

\section{HASIL DAN PEMBAHASAN}

\section{Tingkat Pengungkapan Tanggung Jawab Sosial Perusahaan}

Hasil penelitian tehadap tingkat pengungkapan tanggung jawab sosial perusahaan pada tahun 2005, 2006 dan 2007. Dalam tema lingkungan tidak semua perusahaan mengungkapkan tanggung jawab sosialnya. Terdapat 23 perusahaan yang mengungkapkan tanggungjawabnya terhadap lingkungan pada tahun 2005, tetapi pada tahun 2006 dan 2007 terdapat 28 perusahaan yang mengungkapkan tanggung jawab sosialnya. Rata-rata persentase pengungkapan tanggung jawab sosial perusahaan pada tema lingkungan pada tahun 2005, 2006 dan 2007 adalah 12,34\%, 14,44\%, dan $13,63 \%$.

Untuk tema energi hampir semua perusahaan yang menjadi sample penelitian tidak mengungkapkan tanggung jawab sosialnya. Hanya 10 perusahaan pada tahun 2005, 12 perusahaan pada tahun 2006 dan 13 perusahaan pada tahun 2007 dengan rata-rata persentase pengungkapannya adalah 4,83\%, 7,29\%, dan 9,07\% secara berturut dari tahun 2005, 2006 dan 2007. Pada tema tenaga kerja hampir semua perusahaan mengungkapkan tanggung jawab sosialnya. Hanya 2 perusahaan yang tidak mengungkapkan tanggung jawab sosialnya sedangkan sisanya mengungkapakan tanggung jawab sosialnya pada laporan tahunannya. Berikut rata-rata persentase pengungkapan tanggung jawab tema tenaga kerja secara berturut-turut dari tahun 2005, 2006 dan 2007 yaitu 13,95\%, 16,85\% dan 17,34\%.

Tema produk juga merupakan tema yang selalu diungkapkan oleh perusahaan yang menjadi sample penelitian dengan rata-rata persentase pengungkapan tahun 2005, 2006 dan 2007 berturut-turut adalah sebesar 18,29\%, 22,93\% dan 24,15 \%. Dari 41 perusahaan yang menjadi sample penelitian, terdapat 33 perusahaan pada tahun 2005, terdapat 34 perusahaan pada tahun 2006 dan 2007 yang mengungkapkan tanggung jawab sosialnya pada tema produk. Pada tema keterlibatan masyarakat, hampir semua perusahaan juga mengungkapkan tanggung jawab sosialnya. Dari tahun 2005, 2006 dan 2007 terdapat 7 perusahaan yang tidak melakukan pengungkapan, berarti 34 perusahaan mengungkapkan tanggung jawab sosialnya pada laporan tahunannya. Dengan rata-rata persentase pengungkapan tanggung jawab sosialnya dari tahun 2005 sampai 2007 yaitu 23,95\%, 26,15\% dan $27,44 \%$.

Tema terakhir yang diteliti dalam penelitian ini adalah tema umum yang terdiri dari pengungkapan tujuan perusahaan dalam pengungkapan sosial terhadap masyarakat serta informasi yang berhubungan dengan pengungkapan tanggung jawab sosial selain yang disebutkan dalam kelima tema sebelumnya. Rata-rata persentase pada tema umum adalah 30,49 \% pada tahun 2005 dan 2006, sedangkan pada tahun 2007 yaitu 39,02\%. 
Secara keseluruhan rata-rata perusahaan hanya mengungkapkan 17,24\% untuk seluruh tema pengungkapan tanggung jawab sosial perusahaan. Hasil ini masih relatif sangat rendah jika dibandingkan dengan penelitian yang dilakukan oleh Henny dan Murtanto (2001) yang melakukan peneltian terhadap 58 perusahaan yang go public dengan tingkat pengungkapan sebesar $41.32 \%$. Rendahnya tingkat pengungkapan tanggung jawab sosial perusahaan dalam penelitian ini mungkin karena belum dimanfaatkannya laporan tahunan sebagai media komunikasi antara perusahaan dengan para stakeholders oleh sebagian besar perusahaan atau tidak adanya peraturan yang menjelaskan agar perusahaan mengungkapkan tanggung jawab sosialnya.

\section{Pengaruh Ukuran Perusahaan terhadap Pengungkapan Tanggung Jawab Sosial Perusahaan}

Dari hasil regresi diketahui bahwa variable ukuran perusahaan yang dinilai berdasarkan total asset yang dimiliki oleh perusahaan memiliki p-value 0,027 lebih kecil dari 0,05, maka Ha diterima yang berarti terdapat pengaruh antara ukuran perusahaan terhadap pengungkapan tanggung jawab sosial perusahaan. Bukti bahwa pengungkapan tanggung jawab sosial perusahaan dipengaruhi oleh ukuran perusahaan telah ditemukan dalam penelitian sebelumnya. Hasil penelitian ini mendukung hasil penelitian sebelumnya berkaitan dengan ukuran perusahaan terhadap pengungkapan tanggung jawab sosial perusahaan seperti Kokubu et al, (2001), Hasibuan (2001), Grey et al., (2001), Devina dkk (2004) dan Sembiring (2006). Semua penelitian ini, secara umum menyatakan bahwa semakin besar suatu perusahaan maka pengungkapan tanggung jawab sosial perusahaan yang dibuat juga cenderung semakin luas. Menurut Sembiring (2006), secara teoritis perusahaan besar tidak akan lepas dari tekanan, dan perusahaan yang lebih besar dengan aktivitas dan pengaruh lebih besar terhadap masyarakat mungkin akan memiliki pemegang saham yang memperhatikan program sosial yang dibuat perusahaan sehingga pengungkapan tanggung jawab sosial perusahaan akan semakin luas. Hal ini berarti program tanggung jawab sosial perusahaan juga semakin banyak dan akan diungkapkan dalam laporan tahunan.

\section{Pengaruh Profitabilitas terhadap Pengungkapan Tanggung Jawab Sosial Perusahaan}

Dari hasil regresi diketahui bahwa variable profitabilitas yang diukur menggunakan Return On Asset memiliki p-value 0,615 lebih besar dari 0,05, maka Ha ditolak yang berarti tidak terdapat pengaruh antara profitabilitas terhadap pengungkapan tanggung jawab sosial perusahaan. Hasil penelitian ini sejalan dengan hasil penelitian Kokubu et al.,(2001), Devina dkk (2004) dan Sembiring (2006). Seperti yang dinyatakan oleh Donovan \& Gibson (2000), profitabilitas berpengaruh negative terhadap pengungkapan tanggung jawab sosial perusahaan. Hal ini didukung dengan argumentasi bahwa ketika perusahaan memiliki tingkat laba yang tinggi, perusahaan (manajemen) menganggap tidak perlu melaporkan hal-hal yang dapat mengganggu informasi tentang sukses keuangan perusahaan. Sebaliknya, pada saat tingkat profitabilitas rendah, mereka berharap para pengguna laporan akan membaca good news kinerja perusahaan.

\section{Pengaruh Umur Perusahaan terhadap Pengungkapan Tanggung Jawab Sosial Perusahaan}

Dari hasil regresi diketahui bahwa variable umur perusahaan memiliki p-value 0,006 lebih kecil dari 0,05 , maka Ha diterima yang berarti terdapat pengaruh antara umur perusahaan terhadap pengungkapan tanggung jawab sosial perusahaan. Hasil ini tidak sesuai dengan penelitian yang dilakukan sebelumnya oleh Sembiring (2006). Hasil penelitian ini sejalan dengan penelitian yang dilakukan Owusu-Ansah (2000). Menurut Owusu-Ansah (2000), umur perusahaan sangat mempengaruhi pelaporan keuangan perusahaan, karena berkaitan dengan pengembangan dan pertumbuhan perusahaan. 


\section{Pengaruh Leverage terhadap Pengungkapan Tanggung Jawab Sosial Perusahaan}

Dari hasil regresidiketahui bahwa variable leverage yang dinilai menggunakan Debt to Equity Ratio memiliki p-value 0,005 lebih kecil dari 0,05, maka Ha diterima yang berarti terdapat pengaruh antara leverage terhadap pengungkapan tanggung jawab sosial perusahaan. Hasil ini berbeda dengan penelitian yang dilakukan oleh Sembiring (2006) yang menunjukan tidak terdapat pengaruh antara leverage terhadap pengungkapan tanggung jawab sosial perusahaan. Tetapi hasil ini sejalan dengan penelitian yang dliakukan oleh Rizfathanty (2008) dan mendukung teori agensi, berdasarkan teori agensi, tingkat leverage mempunyai pengaruh negative terhadap pengungkapan tanggung jawab sosial perusahaan. Manajemen perusahaan dengan tingkat leverage yang tinggi cenderung mengurangi pengungkapan tanggung jawab sosial yang dibuatnya agar tidak menjadi sorotan dari para debtholders.

\section{Pengaruh Likuiditas Terhadap Pengungkapan Tanggung Jawab Sosial Perusahaan}

Dari hasil regresi yang terlihat pada table 4.8 diketahui bahwa variable likuiditas yang dinilai menggunakan Current Ratio memiliki p-value 0,002 lebih kecil dari 0,05, maka Ha diterima yang berarti terdapat pengaruh antara likuiditas terhadap pengungkapan tanggung jawab sosial perusahaan. Hasil ini yidak sesuai dengan penelitian yang dilakukan oleh Sembiring (2006) yang menunjukan tidak memiliki pengaruh antara likuiditas terhadap pengungkapan tanggung jawab sosial perusahaan. Tetapi hasil ini mendukung teori agensi dimana manajemen sebagai agen akan berusaha mengungkapkan tanggung jawab sosial perusahaan seminimal mungkin untuk menghindari tekanan dari para debtholders, dan para debtholders memang punya kemungkinan menekan manajemen apabila terlalu banyak berkutat dengan aktivitas sosial karena para debtholders berharap kepentingannya didahulukan daripada aktivitas sosialnya.

\section{Pengaruh Kepemilikan Publik terhadap Pengungkapan Tanggung Jawab Sosial Perusahaan}

Dari hasil regresi yang terlihat pada table 4.8 diketahui bahwa variable kepemilikan publik memiliki $p$-value 0,347 lebih besar dari 0,05, maka Ha ditolak yang berarti tidak terdapat pengaruh antara profitabilitas terhadap pengungkapan tanggung jawab sosial perusahaan. Hal ini mendukung penelitian yang dilakukan oleh Sembiring (2003), hasil ini sulit diargumentasikan karena bagaimana mungkin public yang merupakan bagian dari masyarakat luar perusahaan tidak bereaksi atas masalahmasalah sosial yang ditimbulkan aktivitas perusahaan. Akan tetapi, hal ini mungkin menunjukan bahwa publik sebagai pemilik perusahaan di Indonesia merupakan individu yang terpisah-pisah sehingga kekuatan yang dimiliki untuk menekan manajemen cukup rendah.

\section{PENUTUP}

\section{Simpulan}

Hasil persentase pengungkapan tanggung jawab sosial perusahaan pada tahun 2005, 2006 dan 2007 menunjukan bahwa tema umum yang memiliki persentase terbesar yaitu 30,49 \% pada tahun 2005 dan 2006, sedangkan pada tahun 2007 yaitu 39,02\%. Tetapi, dilihat dari jumlah perusahaan yang mengungkapkannya maka tema tenaga kerja merupakan tema yang banyak diungkapkan oleh perusahaan-perusahaan yang menjadi sample penelitian, dengan rata-rata persentase pengungkapan 
tanggung jawab tema tenaga kerja secara berturut-turut dari tahun 2005, 2006 dan 2007 yaitu 13,95\%, $16,85 \%$ dan $17,34 \%$. Dalam tema lingkungan tidak semua perusahaan mengungkapkan tanggung jawab sosialnya. Terdapat 23 perusahaan yang mengungkapkan tanggungjawabnya terhadap lingkungan pada tahun 2005 dengan rata-rata persentase 12,34\%, pada tahun 2006 dan 2007 terdapat 28 perusahaan dengan rata-rata persentase $14,44 \%$, dan $13,63 \%$.

Untuk tema energi hampir semua perusahaan yang menjadi sample penelitian tidak mengungkapkan tanggung jawab sosialnya. Hanya 10 perusahaan pada tahun 2005, 12 perusahaan pada tahun 2006 dan 13 perusahaan pada tahun 2007 dengan rata-rata persentase pengungkapannya adalah 4,83\%, 7,29\%, dan 9,07\%. Tema produk juga merupakan tema yang selalu diungkapkan oleh perusahaan. Terdapat 33 perusahaan pada tahun 2005, terdapat 34 perusahaan pada tahun 2006 dan 2007, dengan rata-rata persentase pengungkapan berturut-turut adalah sebesar 18,29\%, 22,93\% dan 24,15 \%. Pada tema keterlibatan masyarakat, hampir semua perusahaan juga mengungkapkan tanggung jawab sosialnya. . Dari tahun 2005, 2006 dan 2007 terdapat 34 perusahaan mengungkapkan tanggung jawab sosialnya pada laporan tahunannya. Dengan rata-rata persentase pengungkapan tanggung jawab sosialnya dari tahun 2005 sampai 2007 yaitu 23,95\%, 26,15\% dan 27,44\%. Secara keseluruhan rata-rata perusahaan hanya mengungkapkan $17,24 \%$ untuk seluruh tema pengungkapan tanggung jawab sosial perusahaan.

Ukuran perusahaan mempengaruhi pengungkapan tanggung jawab sosial perusahaan. Terlihat dari hasil regresi, ukuran perusahaan yang dinilai berdasarkan total asset yang dimiliki oleh perusahaan memiliki p-value 0,027 lebih kecil dari 0,05, maka Ha diterima yang berarti terdapat pengaruh antara ukuran perusahaan terhadap pengungkapan tanggung jawab sosial perusahaan. Profitabilitas tidak mempengaruhi pengungkapan tanggung jawab sosial perusahaan. Terlihat dari hasil regresi, profitabilitas yang diukur menggunakan Return On Asset memiliki p-value 0,615 lebih besar dari 0,05 , maka Ha ditolak yang berarti tidak terdapat pengaruh antara profitabilitas terhadap pengungkapan tanggung jawab sosial perusahaan. Umur perusahaan mempengaruhi pengungkapan tanggung jawab sosial perusahaan. Terlihat dari hasil regresi, umur perusahaan memiliki $p$-value 0,006 lebih kecil dari 0,05, maka Ha diterima yang berarti terdapat pengaruh antara umur perusahaan terhadap pengungkapan tanggung jawab sosial perusahaan. Leverage mempengaruhi pengungkapan tanggung jawab sosial perusahaan. Terlihat dari hasil regresi, leverage yang dinilai menggunakan Debt to Equity Ratio memiliki p-value 0,005 lebih kecil dari 0,05, maka Ha diterima yang berarti terdapat pengaruh antara leverage terhadap pengungkapan tanggung jawab sosial perusahaan.

Likuiditas mempengaruhi pengungkapan tanggung jawab sosial perusahaan. Terlihat dari hasil regresi, likuiditas yang dinilai menggunakan Current Ratio memiliki p-value 0,002 lebih kecil dari 0,05, maka Ha diterima yang berarti terdapat pengaruh antara likuiditas terhadap pengungkapan tanggung jawab sosial perusahaan. Kepemilikan publik tidak mempengaruhi pengungkapan tanggung jawab sosial perusahaan. Terlihat dari hasil regresi, kepemilikan publik memiliki $p$-value 0,347 lebih besar dari 0,05, maka Ha ditolak yang berarti tidak terdapat pengaruh antara kepemilikan publik terhadap pengungkapan tanggung jawab sosial perusahaan.

\section{Saran}

Berikut ini adalah beberapa saran yang diberikan peneliti agar pada penelitian berikutnya diharapkan akan mendapatkan hasil yang lebih baik. Diharapkan perusahaan-perusahaan yang telah go public lebih banyak mengungkapkan tanggung jawab sosial perusahaan. Diharapkan perusahaanperusahaan go public dapat memperoleh manfaat dari pengungkapan tanggung jawab sosial yang telah dilakukan perusahaan karena investor lebih tertarik kepada perusahaan yang mengungkapkan tanggung jawab sosialnya pada annual report perusahaan. Diharapkan pihak universitas dapat menjalin kerjasama dengan perusahaan-perusahaan yang sudah terbukti melakukan tanggung jawab sosial yang diungkapkan dalam annual report perusahaan. 


\section{DAFTAR PUSTAKA}

Anggraini, F. R. R., (2006). Pengungkapan Informasi Sosial dan Faktor-Faktor yang Mempengaruhi Pengungkapan Informasi Sosial dalam Laporan Keuangan Tahunan (Studi Empiris pada Perusahaan-Perusahaan yang terdaftar Bursa Efek Jakarta), Simposium Nasional Akuntansi IX, Padang.

Belkaoui, A., \& Karpik, P. G. (1989). Determinants of the Corporate Decision to Disclose Sosial Information, Accounting, Auditing and Accountability Journal, Vol. 2 No. 1, p. 36- 51.

Budiarsi, S. Y. (2005). Corporate sustainability: melalui pendekatan corporate social responsibility. Media Ekonomi, Tahun XV, No.2: 115-135.

Chariri, A., \& Ghozali, I. (2003). Teori akuntansi. Semarang: Universitas Dipenogoro.

Cormier, D., \& Magnan, M. (1999). Corporate environmental disclosure strategies: Determinants, costs, and benefits, Journal of Accounting, Auditing and Finance, Vol. 14, No. 4, pp 429-451.

Devina, F., Zulaikha, \& Suryanto, L. (2004). Pengaruh karakteristik perusahaan terhadap pengungkapan sosial dalam laporan tahunan perusahaan go public di Bursa Efek Jakarta. Jurnal Maksi, Vol. 4, Agustus 2004.

Donovan, G., \& Gibson, K. (2000). Environmental Disclosure in the Corporate Annual Report: A Longitudinal Australian Study. Paper for Presentation in the 6th Interdisciplinary Environmental Association Conference, Montreal, Canada.

Freedman, M., \& Jaggi. M. (1988). An analysis of the association between pollution disclosure and economic performance", Accounting, Auditing \& Accountability Journal, Vol. 1 No. 2, pp. 4358.

Gray, R., Javad, M., Power, D. M., \& Sinclair, C. D. (2001). Social And Environmental Disclosure and Corporate Characteristic: A Research Note And Extension., Journal of Business Finance and Accounting, Vol 28 No. 3, pp 327-356.

Hackstone, D., \& Milne, M. J. (1996). Some determinants of social and environmental disclosures in New Zealand companies. Auditing, Accounting and Accountability Journal, Vol. 9, No. 1, 77108.

Harahap, S. S. (2001). Teori akuntansi. Jakarta: Raja Grafindo Persada.

Hasibuan, R. (2001). Pengaruh Karakteristik Perusahaan Terhadap Pengungkapan Sosial, Tesis, Semarang: Universitas Diponegoro,

Henny \& Murtanto. (2001). Analisis Pengungkapan Sosial pada Laporan Tahunan, Media Riset Akuntansi, Auditing dan Informasi, Vol. 1, no. 2, hal. 21-48

Ikatan Akuntan Indonesia. (2002). Pernyataan standar akuntansi keuangan. Jakarta: Salemba Empat.

Januarti, I., \& Apriyanti, D. (2005). Pengaruh tanggung jawab sosial perusahaan terhadap kinerja perusahaan. Jurnal Maksi, Vol.2, No.5: 227-243. 
Kokubu, K., Shinabe, T., Higashida, A., Onishi, Y., \& Noda, A. (2001). Analysis of Environmental Reports by Japanese Companies - Content Analysis and Determinants, Kobe University Discussion Paper 2001, 25.

Marwata, (2006). Hubungan Karakteristik Perusahaan dan Kualitas Ungkapan Sukarela dalam Laporan Tahunan Perusahaan Publik di Indonesia. Jurnal Ekonomi dan Bisnis, Vol. XII, No. 1, Maret 2006: 59-66.

Owusu-Ansah, S. (2000). Timeliness of Corporate Financial Reporting in Emerging Capital Markets: Empirical Evidence from Zimbabwe Stock Exchange, Accounting and Business Research, Summer.

Purwanto. (2006). New business administration paradigma baru pengelolaan bisnis di era dunia tanpa batas (1st ed.). Yogyakarta: Pustaka Pelajar.

Rajafi, L. R., \& Irianto, G. (2007). Analisis pengungkapan laporan sosial dan lingkungan ssebagai bagian dari triple bottom line reporting dalam akuntansi pertanggungjawaban sosial perusahaan: studi perbandingan rata-rata tema pengungkapan antar kelompok industri yang terdaftar pada bursa efek Jakarta tahun 2005. Tema, Vol.8, No.1:72-91.

Roberts, R.W. (1992). Determinants Of Corporate Social Responsibility Disclosure: An Application Of Stakeholder Theory, Accounting, Organisations and Society, Vol. 17 No. 6, pp. 595-612.

Sembiring, E. R. (2006). Karakteristik perusahaan dan pengungkapan tanggung jawab sosial: study empiris pada perusahaan yang tercatat di BEJ. Jurnal Maksi, Vol. 6, No.1:69-85.

Suda, K., \& Kokubu, K. (1994). Some determinants of environmental disclosure in Japanese companies. Corporate Social Disclosure Work paper.

Utomo (2000). Praktek Pengungkapan Sosial Pada Laporan Tahunan Perusahaan di Indonesia, Proceedings Simposium Nasional Akuntansi 3, hal. 99-122

Yuningsih. (2004). Pengaruh Karakteristik Perusahaan Terhadap Praktek Pengungkapan Tanggung Jawab Sosial dan Lingkungan Perusahaan Publik. Jurnal Akuntansi Keuangan. Balance. Volume 1. No 2. Universitas Muhammadiyah Malang.

Zuhroh, D., \& Sukmawati, I. P. H., (2003). Analisis Pengaruh Luas Pengungkapan Sosial dalam Laporan Tahunan Perusahaan Terhadap Reaksi Investor (Studi Kasus pada PerusahaanPerusahaan High Profile di BEJ), Proceeding Simposium Nasional Akuntansi VI, Universitas Airlangga Surabaya, 16-18 Oktober 2003. 